||||||||||||||||||||||||||||||||||||

企画趣旨

||||||||||||||||||||||||||||||||||||||
表面と真空 Vol. 62, No. 10, p. 592, 2019

特集「二次元層状物質の成長とその場評価

一真空・表面技術による高品質薄膜の実現を目指して一」

https://doi.org/10.1380/vss.62.592

\title{
特集「二次元層状物質の成長とその場評価」企画趣旨
}

\author{
安藤 淳 ${ }^{1}$ ・上野啓司 ${ }^{2}$ - 久保利隆 $1, *$ \\ ${ }^{1}$ 産業技術総合研究所 函305-8568 茨城県つくば市梅園 1-1-1 \\ 2 埼玉大学 大学院理工学研究科 函338-8570 埼玉県さいたま市桜区下大久保 255
}

(2019年 8 月 25 日受付；2019 年 8 月 26 日掲載決定)

\section{Growth and In-situ Observations of Two-Dimensional Layered Materials}

\author{
Atsushi Ando ${ }^{1}$, Keiji Ueno ${ }^{2}$ and Toshitaka Kubo ${ }^{1, *}$ \\ ${ }^{1}$ AIST, Tsukuba Central 2, 1-1-1 Umezono, Tsukuba, Ibaraki 305-8568 \\ ${ }^{2}$ Saitama University, 255 Shimo-Okubo, Sakura-ku, Saitama City, Saitama 338-8570
}

(Received August 25, 2019 ; Accepted August 26, 2019)

\begin{abstract}
Two-dimensional (2D) layered materials have recently attracted much attention for both fundamental studies and future technological applications. To use thin 2D layered materials as next generation devices, well-controlled fabrication and sophisticated measurement are indispensable. In this issue, we present recent situation of growth and in-situ observations of two-dimensional layered materials.
\end{abstract}

KEYWORDS : chemical vapor deposition, two-dimensional layered materials, crystal growth, in-situ observations

二次元層状物質であるグラフェンや単層の遷移金属ダ イカルコゲナイド(Transition metal dichalcogenide, TMDC) 等の機能性原子薄膜材料は, 優れた機械的・光学的・電 気的等の諸物性を有することより, 特異的な物性探索の 基礎研究をはじめとして，電子デバイス，光デバイス， 太陽電池などの様々な応用展開を見据えた研究が，国内 外において精力的に取り組まれている。特に応用展開に むけての高品質結晶成長においては, 近年, 気相成長法 による高品質・大面積薄膜成長の研究に, 急速な進歩が 見られる。

本特集号では, 当該分野における第一線の研究者によ る研究動向分析と将来展望予想を合わせて紹介を行った。 宮田耕充氏には, 面内へテロ構造の合成に関する研究動 向から, TMDC 原子層のへテロ構造に関する直接成長技 術の研究, および積層へテロ構造で観察された「スライ ド可能な原子層」に関する最近の進展を紹介いただいた。 加藤俊顕氏には，グラフェンナノリボンに関する大規模 集積化合成手法, 特異な合成機構, またこれらを活用し

\footnotetext{
*E-mail : t-kubo@aist.go.jp
}

た不揮発性メモリ応用の害証を紹介いただいた。北浦良 氏には, 分子線エピタキシー法による TMDC の結晶成長 を主眼に置きつつ, 関連する話題を紹介いただいた。日 比野祐介氏には，スパッ夕法を用いた $\mathrm{MoS}_{2}$ 成膜におい てスパッタパラメータの調整などによって高品質薄膜や TMDC 混晶の作製可能性の紹介をいただいた。柳瀬隆氏 には, $\mathrm{FeO} ナ ノ$ 粒子触媒を用いた化学気相成長による $\mathrm{MoS}_{2}$ 多層ナノチューブ成長, 他の触媒ナノ粒子の探索, さらに第一原理計算によるナノチューブのひずみエネル ギーや電子状態解析を紹介いただいた。日比野浩樹氏に は, 多結晶 $\mathrm{Ni}$ 箔上でのグラフェン析出と $\mathrm{Ag}(111)$ 基板上 でのシリセン成長を低エネルギー電子顕微鏡によりその 場観察した結果を紹介いただいた。寺澤知潮氏には，化 学気相成長法に打けるグラフェンの成長を熱放射光学顕 微法によりその場観察し, グラフェンの核形成や成長機 構を解析する研究について紹介いただいた。

これらをはじめとする近年の研究の大きな進展によ り, 機能性原子薄膜材料が本来持つ特異で多梯な物性を 最大限発揮させ，これらの材料が広く産業分野に用いら れるようになることを切に願うものである。 